\title{
Trial for the Development of Bio-Functional Foods to Prevent Diabetes and Dementia Using a High-Pressure Treatment
}

\author{
Sumiko Nakamura ${ }^{1}$, Takashi Hara ${ }^{2}$, Akira Yamazaki ${ }^{3}$, Atsushi Kobayashi ${ }^{3}$, Satoshi Maeda ${ }^{3}$, Kensaku \\ Kasuga $^{4}$, Takeshi Ikeuchi ${ }^{4}$, Hiroshi Goto ${ }^{5}$, Masao Hirayama ${ }^{5}$, Kenichi Watanabe ${ }^{5}$, Toshiko Koide ${ }^{5}$, and \\ Ken'ichi Ohtsubo ${ }^{1 *}$
}

\author{
${ }^{1}$ Faculty of Applied Life Sciences, Niigata University of Pharmacy and Applied Life Sciences, 265-1, Higashijima, Akiha-ku, Niigata, 956-8603, Japan \\ ${ }^{2}$ Faculty of Agriculture, Niigata University, 8050, Ninocho, Nishi-ku, Niigata, 950-2181, Japan \\ ${ }^{3}$ Echigo Seika Co., Ltd., 1-4-5, Gofukumachi, Nagaoka, 940-8622, Japan \\ ${ }^{4}$ Department of Molecular Genetics, Brain Research Institute, Niigata University, 1-757, Asahimachidori, Chuo-ku, Niigata, 951-8585, Japan \\ ${ }^{5}$ Niigata Bio-Research Park, Co., Ltd, 316-2, Higashijima, Akiha-ku, Niigata, 956-0841, Japan
}

\begin{abstract}
:
Type-2 diabetes and Alzheimer's disease are very serious diseases and the former has been suggested to be one of the causes of the latter. Low glycemic index foods inhibit rapid increases in blood glucose and insulin secretion after meals. In this study, we investigated the palatability of boiled rice and inhibition of an abrupt increase in blood glucose level (BGL) and amyloid $\beta$ peptide production after eating blend of ordinary unpolished rice, "Koshihikari" and anthocyanin-rich blackrice, "Okunomurasaki" unpolished rice cooked after a high-pressure treatment (HPT KO). "Okunomurasaki" showed a high antioxidant capacity and high inhibitory activity against $\beta$-secretase even after HPT and cooking.

A randomized, single-blind, crossover-designed study was conducted using 15 subjects with a normal BGL. BGLs at 90 and 120 min after ingesting the cooked HPT KO were significantly lower than that for cooked Koshihikari polished rice (p $<0.05)$. Furthermore, the increase in the amyloid $\beta 40$ peptide in the blood 120 min after eating HPT KO tended to be lower than that of cooked Koshihikari polished rice.

It would be necessary to conduct a long-term test using the present HPT KO in terms of inhibitory activity against the abrupt increase of BGL and amyloid $\beta$ peptide production for the probability to prevent type- 2 diabetes and Alzheimer's disease.
\end{abstract}

Keywords: Diabetes; High-pressure treatment; Unpolished-black rice; Alzheimer's disease

\section{Introduction}

Type-2 Diabetes is a lifestyle disease, and its prevention and treatment are extremely important. Low glycemic index (GI) foods inhibit rapid increases in blood glucose and insulin secretion after meals. The glycemic effect of food depends on numerous factors, such as the structure of amylose and amylopectin ${ }^{[1]}$. The amylopectin found in amylose extender (ae) mutants of rice contains a greater number of long-chain glucans, making the rice grain texture very hard and non-sticky after cooking, which renders it less palatable ${ }^{[2]}$.

Resistant starch (RS) is starch that escapes digestion in the small intestine and that may be fermented in the large intestine ${ }^{[3]}$. Four main RS subtypes have been identified based on their source or structure.Amylose-extender (ae) mutant rice grains have markedly higher amounts of RS than other rice grains ${ }^{[4]}$. RS is also expected to promote body fat consumption, and its use over the long term might help to prevent and improve type 2 diabetes ${ }^{[5]}$.

The $\beta$-amyloid precursor protein (APP) generates the amyloid $\beta$ peptide (A $\beta$ ) by $\beta$ and $\gamma$ - secretase in a highly regulated process. As working memory is impaired in Alzheimer's disease (AD), it opens an active area of research to investigate the influence of gamma-aminobutyric acid (GABA) on working memory performance in $\mathrm{AD}^{[6]}$. It is well-recognized that the prevalence of dementia is higher in diabetic patients than in non-diabetic subjects ${ }^{[7]}$, and Tokutake et al. ${ }^{[8]}$ showed that there is a molecular link between $\mathrm{AD}$ and insulin signaling.

The molecules with antioxidant activity contained in rice include phenolic acids, flavonoids, anthocyanins, proanthocyanidins, tocopherols, tocotrienols, $\gamma$-oryzanol, and phytic acid (PA). Rice bran also contains various functional substances, such as $\gamma$-oryzanol, ferulic acid, sterol, wax, ceramide, phytin, inositol, and protein ${ }^{[9]}$. Aliev et al. ${ }^{[10]}$ demonstrated that bran rice and $\gamma$-oryzanol reduced hypothalamic endoplasmic reticulum stress and attenuat-
Received Date: May 23, 2018

Accepted Date: June 20, 2018

Published Date: June 25, 2018

*Corresponding author: Ken'ichi Ohtsubo, Faculty of Applied Life Sciences, Niigata University of Pharmacy and Applied Life Sciences, 265-1, Higashijima, Akiha-ku, Niigata, 9568603, Japan, Tel/Fax: 81-250-251218; E-mail: ohtsubok@nupals.ac.jp

Citation: Nakamura, S., et al. Trial for the Development of Bio-Functional Foods to Prevent Diabetes and Dementia Using a High-Pressure Treatment. (2018) J diab Obes 5(1): 22- 30.

Copyright: (C) 2018 Ohtsubo, K. This is an Open access article distributed under the terms of Creative Commons Attribution 4.0 International License. 
ed the preference for dietary fat in mice. Pigmented rice contains naturally occurring colored substances called anthocyanins that belong to the flavonoid group. Positive health effects from these pigments in the bran layer of rice have been reported; red and black rice decreased atherosclerotic plaque formation and increased the antioxidant status in rabbits due to an enhanced serum high-density lipoprotein cholesterol and apolipoprotein A1 concentration ${ }^{[11]}$. We prepared super-hard rice bread blended with black rice bran, which contained a high amount of RS, and demonstrated its strong inhibitory activity against $\beta$-secretase (BACE1) and acetylcholinesterase even after heating ${ }^{[12]}$.

Of the varied proposed theories of AD etiology, reactive oxygen species (ROS) generation is cited as a common factor. Therefore, efforts to reduce the pathology associated with ROS via antioxidants offers new hope to patients suffering from this devastating disease ${ }^{[10]}$. Abe et al.$^{[13]}$ showed that rice components that included inositol hexaphosphate significantly inhibited $A \beta$ production in neuroblastoma cells without causing cytotoxicity, suggesting that such foods may prevent AD.

High-pressure treatment (HPT) has been recognized as very useful in the food industry ${ }^{[14]}$. HPT is a technological process that limits the negative effects of food preparation on tested hydrosoluble vitamins, thus contributing to the preservation of nutritional quality in foods ${ }^{[15]}$. The combination of HPT and a protease treatment would be effective for the removal of allergenic proteins from rice grains ${ }^{[16]}$. Yamakura et al. ${ }^{[17]}$ showed that HPT before cooking results in an increase in free amino acids and the stickiness of cooked rice. GABA, a bio-functional component in brown rice, was increased by $\mathrm{HPT}^{[18]}$. In previous studies, we developed a novel method for inhibiting abrupt postprandial blood glucose levels (BGLs) in Sprague-Dawley rats through the combination of HPT and preparing cooked rice grains of ae mutant rice (super-hard rice) soaked with functional food ingredients ${ }^{[19]}$.

In the present paper, we investigated the multiple functionalities, the inhibition of both an abrupt increase in BGL and $\mathrm{A} \beta$ peptide production, and evaluated the palatability of boiled unpolished rice after HPT blended Koshihikari with Okunomurasaki at a ratio of 6:4 (HPT KO).

\section{Materials and Methods}

\section{Materials}

The high quality rice Koshihikari, and unpolished-black rice Okunomurasaki, were produced in Yamagata prefecture and purchased from a local market in 2016.

Food processing of experimental diets: HPT KO brown rice was obtained by treating at $200 \mathrm{MPa}$ or $400 \mathrm{MPa}$ for $2 \mathrm{~min}$ in a high-pressure machine (Ishikawajima-Harima Heavy Industries Co., Ltd., Tokyo, Japan), and cooked rice was prepared by Echigo Seika, Co., Ltd. Standard diet rice (cooked Koshihikari white rice; retort cooked rice) was purchased from a local market.

All measurements and analyses were conducted in triplicate after sample preparation or cooking.

Moisture content of rice flour: The moisture content of the unpolished rice and cooked unpolished rice was measured using an oven-drying method. Unpolished rice samples $(2 \mathrm{~g})$ were dried for $1 \mathrm{~h}$ at $135^{\circ} \mathrm{C}$, while cooked rice samples $(2 \mathrm{~g})$ were dried for $3 \mathrm{~h}$ at $135^{\circ} \mathrm{C}$. Cooked rice samples were stored at $-80^{\circ} \mathrm{C}$ followed by lyophilizing in a freeze dryer (FD-1; Tokyo Rikakikai Co., Ltd., Tokyo, Japan). Rice flour was prepared using a cyclone mill (SFC-SI; Udy Corp., Fort Collins, USA) with a screen with $1 \mathrm{~mm}$ diameter pores.

Glucose content: The glucose content was measured by adding $1 \mathrm{~mL}$ of $60 \%$ ethanol to each brown rice flour sample $(0.1 \mathrm{~g})$ and subjecting the mixture to glucose extraction by rotating the tube at $20^{\circ} \mathrm{C}$ for $1 \mathrm{~h}$. The solution was then centrifuged at $1500 \times \mathrm{g}$ for 15 min and the supernatant was collected as the sample solution. The glucose content of the sample solution was measured using the nicotinamide adenine dinucleotide phosphate enzyme assay method with a glucose assay kit (Roche, Darmstadt, Germany).

RS: RS of freeze-dried rice samples was measured according to the official method of AOAC using an RS assay kit (Megazyme Ltd., Wicklow, Ireland). Each sample (0.1g) was digested with pancreatin and amyloglucosidase at $37^{\circ} \mathrm{C}$ for $6 \mathrm{~h}$, and the glucose content was measured using a spectrophotometer at 510 nm.

Polyphenol content: The polyphenol content of freeze-dried rice samples was determined using the Folin-Ciocalteu meth$\mathrm{od}^{[20]}$. The polyphenol content of the test sample $(0.1 \mathrm{~g})$ was extracted with $4 \mathrm{~mL}$ of $80 \%$ ethanol at room temperature for $30 \mathrm{~min}$, and then centrifuged for $10 \mathrm{~min}$ at $3000 \times \mathrm{g}$. The supernatant $(1 \mathrm{~mL})$ was mixed with the same volume of Folin-Ciocalteu solution $(1 \mathrm{~mL})$ and incubated at room temperature for 3 $\mathrm{min}$, followed by the addition of $5 \mathrm{~mL}$ of sodium carbonate and incubation at $50{ }^{\circ} \mathrm{C}$ for $5 \mathrm{~min}$. Finally, the sample solution was cooled in ice water for $1 \mathrm{~h}$ and then centrifuged for $2 \mathrm{~min}$ at 3000 $\times \mathrm{g}$. Absorbance at $765 \mathrm{~nm}$ was measured. Gallic acid was used for the calibration.

Hydrophilic and lipophilic-oxygen radical absorbance capacity: The hydrophilic and lipophilic-oxygen radical absorbance capacity of freeze-dried rice samples was measured as described by Prior et al. ${ }^{[21]}$., Ito et al., and Watanabe et al. ${ }^{[22]}$. For the hydrophilic antioxidant assay, freeze-dried rice flours samples $(0.1 \mathrm{~g})$ were extracted with $10 \mathrm{~mL}$ of hexane at room temperature for $2 \mathrm{~min}$, and then centrifuged for $15 \mathrm{~min}$ at 3000 $\times \mathrm{g}$. The hexane layer was removed and the process was repeated. Residual hexane was evaporated using a water bath at $70^{\circ} \mathrm{C}$ for $10 \mathrm{~min}$, and the residue was then extracted with $10 \mathrm{~mL}$ of acetone/water/acetic acid (70:29.5:0.5, v/v/v). Next, the solution was sonicated (Ultrasonic cleaner 3510J-MTH; Branson Ultrasonics, Emerson Japan, Ltd., Atsugi, Japan) at $37^{\circ} \mathrm{C}$ for $15 \mathrm{~min}$. The tube was maintained at room temperature for $15 \mathrm{~min}$ and then centrifuged for $15 \mathrm{~min}$ at $3000 \times \mathrm{g}$. The supernatant was removed and transferred to a volumetric flask and diluted to 25 $\mathrm{mL}$ total volume.

For the lipophilic antioxidant assay, freeze-dried rice flours samples $(0.1 \mathrm{~g})$ were extracted with $1 \mathrm{~mL}$ of hexane at room temperature for $2 \mathrm{~min}$ and then centrifuged for $15 \mathrm{~min}$ at $3000 \times \mathrm{g}$. The hexane layer was collected and the process repeated. The hexane was evaporated using a water bath at $70^{\circ} \mathrm{C}$ for 10 min, and the dried hexane extract was then dissolved in $250 \mu \mathrm{L}$ 
of acetone and diluted with $750 \mu \mathrm{L}$ of $7 \%$ randomly methylated $\beta$-cyclodextrin [0.7 g of methyl- $\beta$-cyclodextrin; (Sigma-Aldrich Japan Co., Tokyo, Japan) dissolved in $10 \mathrm{~mL}$ of $50 \%$ acetone]. Trolox calibration solutions $(50,25,12.5$, and $6.25 \mu \mathrm{mol} / \mathrm{L}$ in an assay buffer solution) were made to obtain a standard curve. A fluorimeter 96-well plate was used. Absorbance values were measured at $485 \mathrm{~nm}$ (excitation) and $530 \mathrm{~nm}$ (emission) using a fluorescent microplate reader (Grating Based Multimode Reader SH-9000; Corona Electric Co, Ltd., Hitachinaka, Japan). The trolox calibration solutions, blank (dilute buffer), diluted test samples $(35 \mu \mathrm{L})$, fluorescein solution $(115 \mu \mathrm{L}, 110.7 \mathrm{nmol} / \mathrm{L})$, and 2,2'-azobis (2-methylpropion amidine) dihydrochloride (AAPH) solution [50 $\mu \mathrm{L}, 31.7 \mathrm{mmol} / \mathrm{L}$ : hydrophilic-oxygen radical absorbance capacity (H-ORAC), $63.4 \mathrm{mmol} / \mathrm{L}$ : lipophilic-oxygen radical absorbance capacity (L-ORAC)] were added in order, and measurements were taken immediately at $37^{\circ} \mathrm{C}$ for $90 \mathrm{~min}$.

Angiotensin-converting enzyme (ACE) inhibitor activity: ACE inhibitor activity of freeze-dried rice samples was determined using an ACE kit-WST (Dojindo Laboratories, Co. LLC, Kumamoto, Japan). To obtain the measurements, test samples $(0.1 \mathrm{~g})$ were extracted with $0.5 \mathrm{~mL}$ of distilled water at room temperature for $1 \mathrm{~h}$ and then centrifuged for $15 \mathrm{~min}$ at $1000 \times$ g. An adsorption filter (MILLEX-GN33 mm; Merck Millipore Ltd., Carrigtwohill, Ireland) was used to remove the colored component from the extraction solution. A 96-well plate was used. Absorbance values at $450 \mathrm{~nm}$ were measured using a fluorescent microplate reader. Captopril (CA) was used for the calibration.

BACE1 inhibitory activity: BACE1 inhibitory activity of freeze-dried rice bran, brown rice breads, and commercial feed was determined using a BACE1 activity detection kit (Fluorescent; Sigma-Aldrich Japan Co., Tokyo, Japan). To obtain the measurements, rice flour $(0.1 \mathrm{~g})$ was extracted with $0.5 \mathrm{~mL}$ of $10 \mathrm{mM}$ acetate buffer solution ( $\mathrm{pH} 5.0$, including $0.1 \%$ Triton and $0.05 \%$ CHAPS) at room temperature for $1 \mathrm{~h}$ and then centrifuged for $15 \mathrm{~min}$ at $1000 \times \mathrm{g}$. An adsorption filter was used to remove the colored component from the extraction solution. A 96-well plate (tissue culture plate) was used for fluorimetry. The fluorescent buffer $(78 \mu \mathrm{L})$, extraction solution $(30 \mu \mathrm{L})$ (the blank was set without a fluorescent buffer), and $0.015 \mathrm{U} / \mu \mathrm{L}$ enzyme $(10 \mu \mathrm{L})$ were added in order and then pre-incubated at $37^{\circ} \mathrm{C}$ for $10 \mathrm{~min}$. Next, a $50 \mu \mathrm{M}$ substrate $(20 \mu \mathrm{L})$ was added and the reaction mixture was covered with Parafilm and incubated at $37^{\circ} \mathrm{C}$ for $2 \mathrm{~h}$. Absorbance values were measured at $320 \mathrm{~nm}$ (excitation) and $405 \mathrm{~nm}$ (emission) using a fluorescent microplate reader (Grating Based Multimode Reader SH-9000: Corona Electric Co, Ltd.). In our preliminary experiment, it was shown that phytic acid (PA, reference material) inhibited the activity of a $0.03 \mathrm{U} / \mu \mathrm{L}$ enzyme solution $(10 \mu \mathrm{L})$ of BACE1.

Physical properties of cooked rice: The physical properties of cooked rice grains were measured based on a bulk measurement (10g) using a My Boy System Tensipresser (Taketomo Electric Co., Tokyo, Japan), according to the method described by Okadome et al. ${ }^{[23]}$. The bulk measurements were taken six times and the mean value was calculated.
Enzyme-linked immunosorbent assay (ELISA): We used ELISA with site-specific monoclonal antibodies to detect A $\beta 40$ using a human/rat $\beta$ Amyloid (40) Sandwich ELISA kit II (FUJIFILM Wako Pure Chemical Co., Osaka, Japan). Blood plasma was diluted with a dilution buffer (4-fold dilution), mixed with a standard solution, and incubated overnight in a refrigerator before being washed five times. Horseradish peroxidase antibody standard product $(100 \mu \mathrm{L})$ was then added and the mixture was incubated in a refrigerator for $1 \mathrm{~h}$, followed by washing five times. Finally, $100 \mu \mathrm{L}$ of 3,3',5,5'-tetramethylbenzidine was added, the mixture was covered with aluminum foil, and incubated at room temperature for $0.5 \mathrm{~h}$. A stop solution $(100 \mu \mathrm{L})$ was added and absorbance was measured immediately at 450 $\mathrm{nm}$ using a fluorescent microplate reader. The A $\beta 40$ content was calculated according to the calibration using a standard sample and test samples.

Study design: Fifteen normal, healthy human subjects (4 male, 11 female) were recruited for the study (fasting blood sugar level: $79-99 \mathrm{mg} / \mathrm{dL}$; mean $=89.53 \mathrm{mg} / \mathrm{dL}$; body mass index: $15.5-23.6 \mathrm{~kg} / \mathrm{m}^{2}$; mean $=20.5 \mathrm{~kg} / \mathrm{m}^{2}$ ). The tests were grouped into two blocks. The protocol was approved by Niigata Bio-Research Park Inc. BGLs and insulin levels were measured at 0, 30, 60,90 , and $120 \mathrm{~min}$ after the 15 subjects had eaten two different test meals. Test meals were consumed within 10 min with frequent mastication (30 times was the guide) and contained $50 \mathrm{~g}$ of carbohydrates plus $200 \mathrm{~mL}$ of water. There was a $7 \mathrm{~d}$ washout between each period.

This test was conducted in February and March of 2017 as a cross-over test of two groups with the approval of the ethical committee for human tests of the Niigata Bio-research Park and Niigata University of Pharmacy and Applied Life Sciences and according to the 2014 guidelines issued by the Ministry of Education, Culture, Sports, Science, and Technology, and the Ministry of Health, Labour, and Welfare, Japan. This test was registered as UMIN000025642.

Statistical analyses: All of the results were subjected to t-test using Excel Statistics (ver. 6, Microsoft Corporation, Tokyo, Japan).

\section{Results and Discussion}

Glucose content: During the early stage of cooking, $\alpha$-amylase, $\beta$-amylase, and $\alpha$-glucosidase decompose starch and generate glucose. As shown in Table 1, the glucose content of cooked HPT KO were significantly higher than that of cooked Koshihikari polished rice $(p<0.05)$. The glucose content was almost identical between HPT (200 MPa 2 min) samples and untreated cooked unpolished rice (Supplementary Table 1). 
Citation: Ohtsubo, K., et al. Trial for the Development of Bio-Functional Foods to Prevent Diabetes and Dementia Using a High-Pressure Treatment. (2018) J diab Obes 5(1): 22- 30 .

Table 1: Bio-functional properties of raw rice and cooked samples.

\begin{tabular}{|c|c|c|c|c|c|c|c|c|c|}
\hline & $\begin{array}{c}\text { Glucose content } \\
(\mathrm{g} / \mathbf{1 0 0 g})\end{array}$ & & SD & $\begin{array}{c}\text { Resistant starch } \\
(\%)\end{array}$ & & SD & $\begin{array}{l}\text { Polyphenol content } \\
\text { (GAEmg/100gFW) }\end{array}$ & & SD \\
\hline Koshihikari cooked polished rice & 0.004 & $\mathrm{a}$ & 0.001 & 0.67 & $\mathrm{a}$ & 0.05 & 4.83 & $\mathrm{a}$ & 0 \\
\hline HPT KO cooked unpolished rice & 0.08 & $\mathrm{~b}$ & 0 & 1.19 & $\mathrm{~b}$ & 0.06 & 11.58 & $\mathrm{~b}$ & 0.03 \\
\hline Koshihikari polished rice & 0.184 & $\mathrm{a}$ & 0.01 & 0.52 & $\mathrm{a}$ & 0.01 & 8.04 & $\mathfrak{a}$ & 0.1 \\
\hline Koshihikari unpolished rice & 0.16 & $\mathrm{~b}$ & 0.01 & 0.65 & $\mathrm{~b}$ & 0.01 & 10.61 & $\mathrm{~b}$ & 0.21 \\
\hline \multirow[t]{2}{*}{ Okunomurasaki unpolished rice } & 0.16 & $\mathrm{~b}$ & 0.01 & 0.89 & $\mathrm{c}$ & 0.01 & 17.12 & $\mathrm{c}$ & 0.47 \\
\hline & $\begin{array}{c}\text { L-ORAC } \mu \mathrm{mol} \\
\text { TE/100gFW }\end{array}$ & & SD & $\begin{array}{c}\text { H-ORAC } \mu \mathrm{mol} \\
\text { TE/100gFW }\end{array}$ & & SD & $\begin{array}{c}\beta \text { - Secretase inhibition rate } \\
(0.27 \mu \mathrm{g}-\mathrm{eq} / \mu \mathrm{L})\end{array}$ & & SD \\
\hline Koshihikari cooked polished rice & 0.37 & $\mathrm{a}$ & 0 & 6.3 & $\mathrm{a}$ & 0.85 & - & $\mathrm{a}$ & 0 \\
\hline HPT KO cooked unpolished rice & 4.6 & $\mathrm{~b}$ & 0.01 & 75.5 & $\mathrm{~b}$ & 1.16 & 12 & $\mathrm{~b}$ & 3.4 \\
\hline Koshihikari polished rice & 2.9 & $\mathrm{a}$ & 0.1 & 31.5 & $\mathrm{a}$ & 1.2 & - & $\mathrm{a}$ & 0 \\
\hline Koshihikari unpolished rice & 4.4 & $\mathrm{~b}$ & 0.2 & 41.6 & $\mathrm{~b}$ & 3.1 & 14 & $\mathrm{~b}$ & 0 \\
\hline Okunomurasaki unpolished rice & 5.3 & $\mathrm{c}$ & 0.1 & 285.8 & $\mathrm{c}$ & 7.8 & 29 & $\mathrm{c}$ & 0 \\
\hline
\end{tabular}

HPT, high-pressure treatment; KO unpolished rice ,blend Koshihikari and Okunomurasaki (6:4) unpolished rice.

Significant difference $(p<0.05)$ among the two cooked rice and the three raw rice is shown by a, b, and c.

$R S$. RS is a starch that escapes digestion in the small intestine and that may be fermented in the large intestine. As shown in Table 1 , RS content was 1.8-fold higher in cooked HPT KO unpolished rice compared with that in cooked Koshihikari polished rice $(p<$ $0.01)$.

In terms of HPT (200 MPa $2 \mathrm{~min}$ ) effect on the RS of cooked unpolished rice, HPT showed an increase of about 1.3 times compared to Koshihikari and 1.2 times compared to Okunomurasaki without HPT according to supplementary Table 1.

Supplementary Table 1: Component analysis of HPT and untreated cooked brown rice.

\begin{tabular}{|c|c|c|c|c|c|c|c|c|c|}
\hline & $\begin{array}{c}\text { Glucose content } \\
(\mathrm{g} / \mathbf{1 0 0 g})\end{array}$ & & SD & $\begin{array}{c}\text { Resistant } \\
\operatorname{starch}(\%)\end{array}$ & & SD & $\begin{array}{l}\text { Polyphenol content } \\
\text { (GAEmg/100gFW) }\end{array}$ & & SD \\
\hline Koshihikari cooked unpolished rice & 0.17 & $\mathrm{a}$ & 0.01 & 0.22 & $\mathrm{a}$ & 0.01 & 12.3 & $\mathrm{a}$ & 0.61 \\
\hline $\begin{array}{l}\text { Koshihikari cooked unpolished rice (HPT: } \\
\text { 200MPa } 2 \mathrm{~min} \text { ) }\end{array}$ & 0.16 & $\mathrm{a}$ & 0.01 & 0.28 & $\mathrm{~b}$ & 0.02 & 11.3 & $\mathrm{a}$ & 0.08 \\
\hline Okunomurasaki cooked unpolished rice & 0.12 & $\mathrm{a}$ & 0 & 0.26 & $\mathrm{a}$ & 0.01 & 35.5 & $\mathrm{a}$ & 0.31 \\
\hline $\begin{array}{l}\text { Okunomurasaki cooked unpolished rice } \\
\text { (HPT: 200MPa 2min) }\end{array}$ & 0.12 & $\mathrm{a}$ & 0.002 & 0.3 & $\mathrm{~b}$ & 0.02 & 39.9 & $\mathrm{~b}$ & 0.46 \\
\hline
\end{tabular}

Polyphenol content: Fruits and vegetables are rich sources of plant polyphenols and flavonoids, which are suggested to be the main agents that reduce the risk of cardiovascular disease ${ }^{[25]}$. As shown in Table 1, the polyphenol content was 2.4-fold higher in cooked HPT KO unpolished rice compared to that of cooked Koshihikari polished rice, with significant differences at $p<0.01$. A high amount of polyphenol is effective at preventing oxidation in vivo after ingestion.

In terms of the effect of HPT (200 MPa $2 \mathrm{~min}$ ) on the polyphenol content of cooked unpolished rice, a decrease to about $8 \%$ was observed in Koshihikari without HPT and a 1.1-fold increase was observed in Okunomurasaki according to supplementary Table 1.

H-ORAC and L-ORAC: Many dietary compounds have been suggested to be important antioxidants, and while evidence to support the key role that vitamins $\mathrm{E}$ and $\mathrm{C}$ play has been produced, that for carotenoids and related plant pigments is weaker ${ }^{[26]}$. 

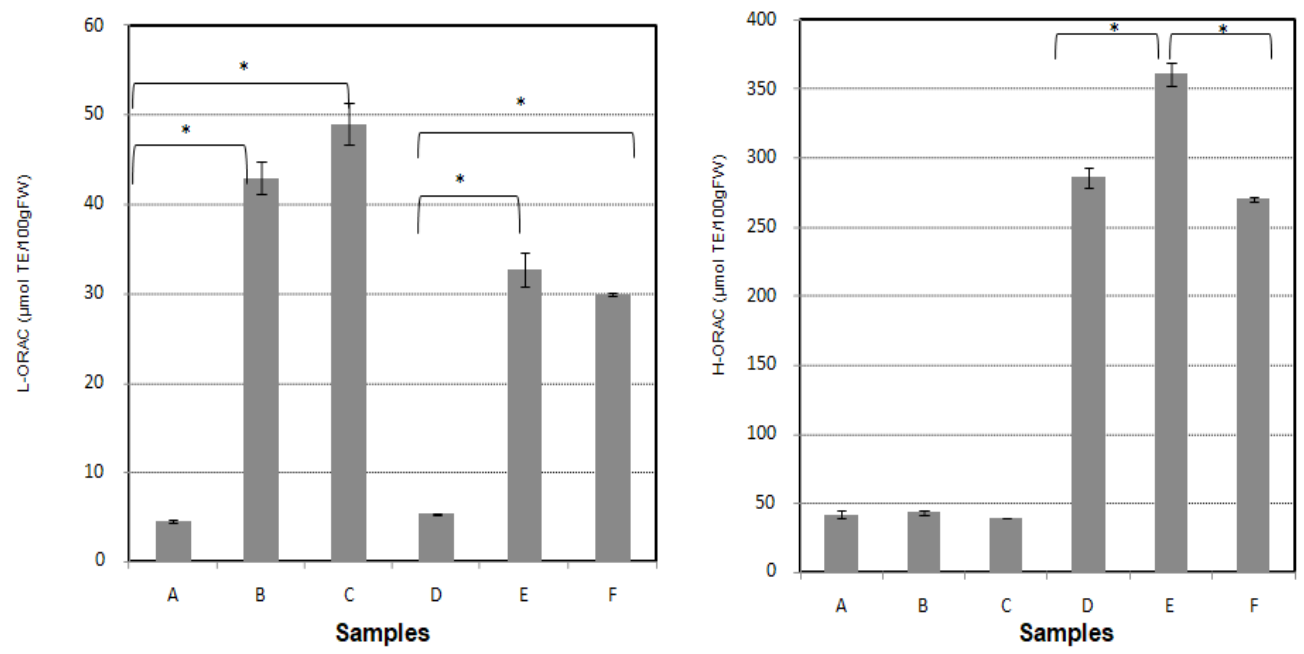

Figure 1: Effect of HPT on ORAC of various unpolished rice samples. A: Koshihikari unpolished rice, B; Koshihikari unpolished rice (200MPa HPT), C; Koshihikari unpolished rice (400MPa HPT), D; Unpolished black rice of Okunomurasaki (200MPa HPT), F; Unpoplished rice of Okunomurasaki (400MPa HPT).

Notes: Anasterisk denotes a significant difference $(p<0.05)$

As shown in Figure 1, L-ORAC values of ordinary unpolished rice Koshihikari and unpolished black rice Okunomurasaki were markedly increased by a treatment at $200 \mathrm{MPa}$ for $2 \mathrm{~min}$ and at $400 \mathrm{MPa}$ for $2 \mathrm{~min}$ in an HPT machine. Thus, lipophilic antioxidant substances are increased by HPT. This may have been caused by damage to organelle's cell walls and membranes, such as spherosomes, which liberate or make free lipophilic antioxidants such as tochopherol. Conversely, H-ORAC values in unpolished black rice were much higher than those of Koshihikari (Figure 1). It seems that the anthocyanin in unpolished black rice plays a principal role in H-ORAC values. The hydrophilic antioxidant anthocyanin reacts more effectively to HPT (200 MPa). We found that anthocyanin is decomposed a little by excess HPT such as at $400 \mathrm{MPa}$.

As shown in Table 1, L-ORAC was 12.4-fold higher in cooked HPT KO unpolished rice compared to that in cooked Koshihikari polished rice $(p<0.01)$. H-ORAC was 12.0-fold higher in cooked HPT KO unpolished rice compared with that in cooked Koshihikari polished rice ( $p<0.01$ and $p<0.05$, respectively). The main reason for higher ORAC values in HPT KO is due to the effect of antioxidant substances in unpolished rice. H-ORAC was significantly, positively correlated with polyphenol content (data not shown). HPT KO unpolished rice seems to be promising in extinguishing active oxygen in vivo.

Tsuda et al..$^{[27]}$ showed that anthocyanins extracted from purple corn prevented obesity and ameliorated hyperglycemia in mice. Moreover, Suzuki et al.$^{[28]}$ showed that the calcium content of pigmented brown rice was higher than that of the Koshihikari cultivar. These experiments suggest that anthocyanins, as a functional food component, can aid in preventing oxidation in vivo.

ACE inhibitor activity: A number of cross-sectional studies have shown an inverse relationship between blood pressure and the prevalence of dementia and $\mathrm{AD}^{[28]}$. GABA has attracted considerable attention as an inhibitory amino acid which lowers blood pressure in mammals ${ }^{[29]}$. Several free amino acids were increased in unpolished rice after pressure treatment and soaking ${ }^{[18]}$. Tsushida et al. ${ }^{[30]}$ showed that the $\gamma$-aminobutyric acid and alanine content in tea leaves increased after they were incubated in nitrogen or carbon dioxide gas under anaerobic conditions. In a previous study, we showed that the GABA content in pre-germinated unpolished rice prepared by soaking in a $2 \%$ red onion solution was increased 2.3 -fold compared to non-soaked unpolished rice ${ }^{[4]}$. Uchida $e t$ $a l$. showed that the inhibitory effects of condensed tannins on the activities of ACE are specific. Hara et al. ${ }^{[31]}$ demonstrated that the polyphenolic components catechin and the aflavins in tea had a notable ACE inhibitor effect. The ACE inhibition rate was converted to a $\mathrm{CA}$ (reference material) equivalent. In our preliminary experiment, the half maximal inhibitory concentration $\left(\mathrm{IC}_{50}\right)$ of $\mathrm{CA}$ was $3.45 \mathrm{ng} / \mu \mathrm{L}$. The equation has a determination coefficient $\left(\mathrm{R}^{2}\right)$ of 0.98 . As shown in Table 1, the $\mathrm{IC}_{50}$ of cooked Koshihikari polished rice was $638.60 \mu \mathrm{g}-\mathrm{CA}$ eq./ $\mu \mathrm{L}$, that of cooked HPT KO unpolished rice was $61.20 \mu \mathrm{g}-\mathrm{CA}$ eq./ $\mu \mathrm{L}$. The ACE inhibition rate was 10.4-fold higher in cooked HPT KO unpolished rice compared with the cooked Koshihikari polished rice, with significant differences at $\mathrm{p}<0.01$.

BACE1 inhibitory activity: BACE1 is the first protease in the process of converting APP into A $\beta$ in the brain. Table 1 shows that unpolished black rice (Okunomurasaki) has the highest BACE1 inhibition (29.0\%) among the 2 kinds of raw rice (Koshihikari polished rice; $0.00 \%$, Koshihikari unpolished rice; $14.0 \%$ ). And after cooking, only HPT KO showed BACE1 inhibitory activity $(12.0 \%)$ although Koshihikari polished rice did not show BACE1 inhibitory activity. These results indicate that the BACE1 inhibitory activity of pigmented rice bran is much stronger than that of ordinary rice bran, as we reported in our previous paper ${ }^{[12]}$. 
Citation: Ohtsubo, K., et al. Trial for the Development of Bio-Functional Foods to Prevent Diabetes and Dementia Using a High-Pressure Treatment. (2018) J diab Obes 5(1): 22- 30 .

Table 2: Physical properties of rice cooked samples.

\begin{tabular}{|c|c|c|c|c|c|c|c|c|c|c|c|c|}
\hline & $\begin{array}{c}\text { Hardness } \\
\left(\mathrm{gw} / \mathrm{cm}^{2}\right)\end{array}$ & & D & $\begin{array}{l}\text { Toughness } \\
\left(\mathrm{gw} / \mathrm{cm}^{2}\right)\end{array}$ & & D & $\begin{array}{l}\text { Adhesion } \\
\left(\mathrm{gw} / \mathrm{cm}^{2}\right)\end{array}$ & & D & $\begin{array}{c}\text { Stickiness } \\
\left(\mathrm{gw} / \mathrm{cm}^{2}\right)\end{array}$ & & D \\
\hline Koshihikari cooked polished rice & 6.5 & $\mathrm{a}$ & 0.4 & 25.8 & $\mathrm{a}$ & 1.9 & 30.4 & $\mathrm{a}$ & 7.3 & 43.5 & $\mathrm{a}$ & 11.2 \\
\hline HPT KO cooked unpolished rice & 20.5 & $\mathrm{~b}$ & 3.5 & 39.6 & $\mathrm{~b}$ & 5.1 & 20 & $\mathrm{~b}$ & 8.2 & 33.2 & $\mathrm{~b}$ & 6 \\
\hline
\end{tabular}

HPT, high-pressure treatment; KO unpolished rice ,blend Koshihikari and Okunomurasaki (6:4) unpolished rice.

Significant difference $(p<0.05)$ among the two cooked rice is shown by a and $\mathrm{b}$.

Physical properties of cooked rice: As shown in Table 2, the physical properties of cooked rice were measured in bulk using a Tensipresser. Differences were detected in hardness, toughness, adhesion, and stickiness values, which are important indices when evaluating the palatability of rice ${ }^{[24]}$, with toughness showing a similar tendency to hardness.

The hardness value was 3.2-fold higher in cooked HPT KO unpolished rice compared with that of cooked Koshihikari polished rice. The toughness value showed a similar tendency to the hardness value; however, the stickiness value was 0.66 -fold lower in cooked HPT KO unpolished rice compared with cooked Koshihikari polished rice. The adhesion value showed a similar tendency to the stickiness value.

HPT KO cooked unpolished rice would be accepted because of the improvement to its physical properties by HPT. As shown in supplementary Table 2, which compares the effects of HPT on physical properties using identical rice cultivars, HPT decreased hardness and toughness and increased adhesion 1.2 - 1.4 times of Koshihikari and Okunomurasaki.

Supplementary Table 2: Physical properties of HPT and untreated cooked brown rice.

\begin{tabular}{|c|c|c|c|c|c|c|c|c|c|c|c|c|}
\hline & $\begin{array}{r}\text { Hardness } \\
\left(\mathrm{gw} / \mathrm{cm}^{2}\right)\end{array}$ & & SD & $\begin{array}{l}\text { Toughness } \\
\left(\mathrm{gw} / \mathrm{cm}^{2}\right)\end{array}$ & & SD & $\begin{array}{c}\text { Adhesion } \\
\left(\mathrm{gw} / \mathrm{cm}^{2}\right)\end{array}$ & & SD & $\begin{array}{c}\text { Stickiness } \\
\left(\mathrm{gw} / \mathrm{cm}^{2}\right)\end{array}$ & & SD \\
\hline Koshihikari cooked unpolished rice & 11.5 & $\mathrm{a}$ & 1.5 & 21.5 & $\mathrm{a}$ & 0.7 & 20.5 & $\mathrm{a}$ & 11.1 & 13.1 & $\mathrm{a}$ & 1 \\
\hline $\begin{array}{l}\text { Koshihikari cooked unpolished } \\
\text { rice(HPT: 200MPa } 2 \text { min) }\end{array}$ & 9 & $\mathrm{~b}$ & 2.2 & 17.7 & $\mathrm{~b}$ & 0.8 & 24.2 & $\mathrm{~b}$ & 16.4 & 9.7 & $\mathrm{~b}$ & 4.1 \\
\hline Okunomurasaki cooked unpolished rice & 14.3 & $\mathrm{a}$ & 1.3 & 24.3 & $\mathfrak{a}$ & 1.8 & 23.8 & $\mathrm{a}$ & 4.8 & 7 & $\mathrm{a}$ & 1.5 \\
\hline $\begin{array}{l}\text { Okunomurasaki cooked unpolished } \\
\text { rice(HPT: 200MPa } 2 \text { min) }\end{array}$ & 11.7 & $\mathrm{~b}$ & 0.9 & 20.4 & $\mathrm{~b}$ & 0.7 & 33.7 & $\mathrm{~b}$ & 5.1 & 11.3 & $\mathrm{~b}$ & 0.7 \\
\hline
\end{tabular}

Significant difference $(p<0.05)$ between the two cooked rice is shown by a and $\mathrm{b}$.

Changes in postprandial BGL and area under the curve (AUC) in human (15 subjects): Panlasigui and Thompson ${ }^{[32]}$ showed that unpolished rice is a healthier and more beneficial food for diabetics and hyperglycemic individuals than polished rice, and that the glycemic area and GI were 35.4\% lower in unpolished rice than in polished rice. Jung et al ${ }^{[33]}$. showed that ferulic acid may be beneficial in the treatment of type- 2 diabetes because it regulates BGLs by elevating glucokinase activity and the production of glycogen in the liver.

BGL and AUC after the two different tests are shown in Figure 2 and Figure 3. BGLs at 90 min or 120 min after eating the HPT KO cooked unpolished rice (open bar) showed significant lower values compared with cooked Koshihikari polished rice (closed bar).

(A)

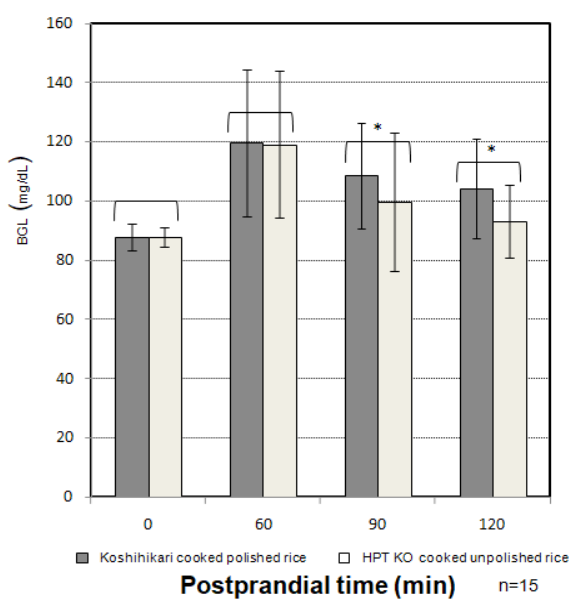

(B)

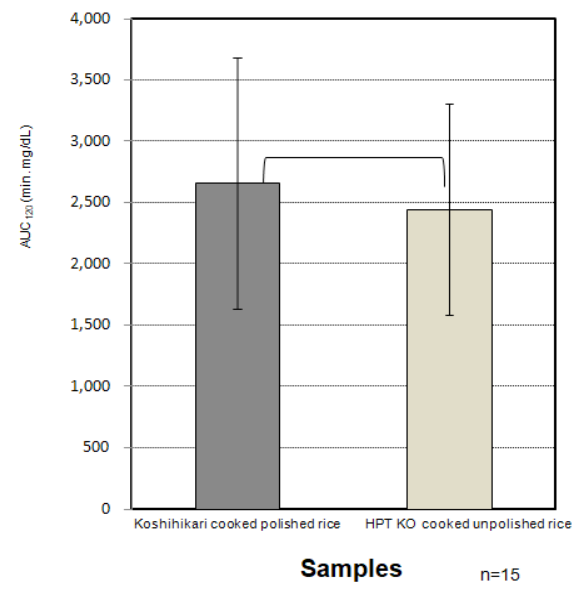

Figure 2: Changes in BGL and AUC in 15 subjects after eating HPT KO cooked unpolished rice. (A) BGL (15 subjects). (B) AUC (15 subjects) HPT, high-pressure treatment; KO, unpolished rice, blend of Koshihikari and Okunomurasaki (ratio was 6:4) BGL, blood glucose level; AUC, area under the curve. Closed bar; Koshihikari cooked polished rice. Open bar; HPT KO cooked unpolished rice. An asterisk denotes a significant difference $(p<0.05)$ 
(A)

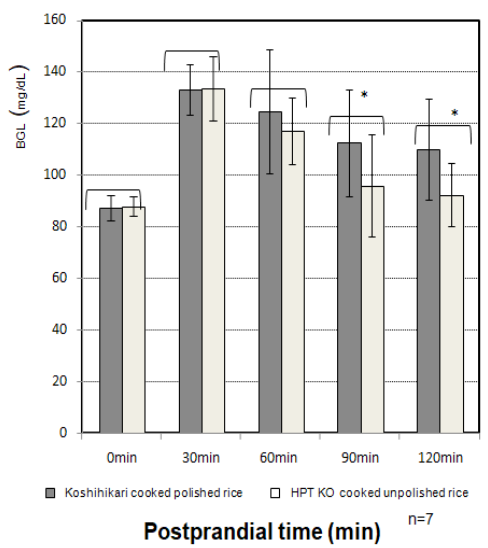

(B)

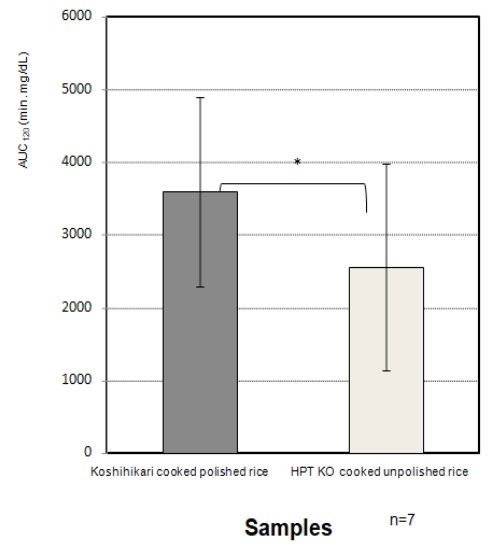

Figure 3: Changes in BGL in subjects with a high initial BGL after eating HPT KO cooked unpolished rice

(A) BGL at 30, 60, 90, and 120 min ( $\mathrm{n}=7$ subjects).

(B) AUC at 120 min.HPT, high-pressure treatment; KO, unpolished rice, blend of Koshihikari and Okunomurasaki (ratio was 6:4). BGL, blood glucose level.AUC, area under the curve.

Closed bar; Koshihikari cooked polished rice. Open bar; HPT KO cooked unpolished rice.

An asterisk denotes a significant difference $(p<0.05)$

Changes in postprandial BGL and AUC in humans (seven subjects with higher BGLs): It was reported that GI varies depending on the subjects (e.g., young men and women ${ }^{[34]}$ ), so we divided the 15 subjects into two groups; a high BGL subclass (seven subjects) and a low BGL subclass (eight subjects).

As shown in Figure 2 (A), BGL at 90, and 120 min after eating cooked HPT KOunpolished rice for 15 subjects showed a significantly lower BGL compared with that after eating cooked Koshihikari polished rice $(p<0.05)$. Figure 2 (B) shows that AUC was not significantly lower compared with that of cooked Koshihikari polished rice 120 min after eating $(p<0.05)$.

AS shown in Figure 3 (A), BGL at $90 \mathrm{~min}$ and $120 \mathrm{~min}$ after eating cooked HPT KO unpolished rice for high BGL subjects $(\mathrm{n}=7)$ showed a significantly lower BGL compared with that after eating cooked Koshihikari polished rice $(p<0.05)$. Figure $3(\mathrm{~B})$ also shows that AUC was significantly lower compared with cooked Koshihikari white rice 120 min after eating $(p<0.05)$.

Low BGL subjects showed no significant difference in BGL or AUC after eating cooked unpolished and Koshihikari polished rice. HPT KO cooked unpolished rice was shown to be very effective in retarding the abrupt BGL increase, especially in high initial BGL subjects. Furthermore, GI were 100 for cooked Koshihikari polished rice and 97 for HPT KO cooked unpolished rice.

Table 3: Changes in amyloid $\beta$ peptides before and after meal.

\begin{tabular}{|c|c|c|c|c|c|c|c|c|}
\hline \multirow{2}{*}{$(\mathrm{pg} / \mathrm{mL})$} & \multicolumn{4}{|c|}{ Koshihikari cooked polished rice } & \multicolumn{4}{|c|}{ HPT KO cooked unpolished rice } \\
\hline & Before the meal & SD & Postprandial (120min) & SD & Before the meal & SD & Postprandial (120min) & SD \\
\hline Amyloid- $\beta 40$ & 139.3 & 25 & 142.3 & a 20 & 144.2 & a 25 & 144.7 & a 21 \\
\hline Amyloid- $\beta 42$ & 8.5 & a 4.3 & 8.9 & 4 & 8.6 & 4 & 9.1 & $\mathrm{a}$ \\
\hline
\end{tabular}

HPT, high-pressure treatment; KO unpolished rice ,blend Koshihikari and Okunomurasaki (6:4) unpolished rice.

Significant difference $(p<0.05)$ among the differences between amyloid- $\beta$ before the meal and postprandial among the three cooked rice was not shown.

Significant difference $(p<0.05)$ among the two cooked rice is shown by a and $\mathrm{b}$.

Characterization of amyloid $\beta-40$ peptide species by ELISA: Blood samples were taken from the 15 subjects before and 120 min after the meal. As shown in Table 3, ELISA was used with site-specific monoclonal antibodies to detect A $\beta 40$.

The increase in A $\beta 40120 \mathrm{~min}$ after the meal was $0.5 \mathrm{pg} / \mathrm{mL}(144.7-144.2=0.5 \mathrm{pg} / \mathrm{mL})$ for HPT KO, 3.0 pg/mL (142.3$139.3=3.0 \mathrm{pg} / \mathrm{mL})$ for Koshihikari polished rice. Therefore, HPT KO showed 6.0 fold (3.0/0.5) lower amyloid $\beta-40$ compared with cooked Koshihikari polished rice. The BACE1 inhibitory activity of HPT KO may have played a role in lowering A $\beta$ after the meal. Further long-term human testing is needed to detect the change in $\mathrm{A} \beta$ using these rice samples.

\section{Conclusions}

As type-2 diabetes has been shown to increase the risk of $\mathrm{AD}$, we investigated the potential of food products to prevent amyloid $\beta$ generation and abrupt increases in BGLs that are resistant to digestion (hard and non-sticky texture of rice grains) and possess a BACE1 inhibitory activity and antioxidant capacity (anthocyanin pigments). To find neuroactive and slow-digesting compounds with a potent inhibitory effect on BACE1 and ACE, and a polyphenol content from natural sources, we evaluated HPT cooked unpolished black rice. 
The following are the main findings of our study:

1. The texture of cooked HPT KO unpolished rice grains became more palatable following HPT. Its antioxidant capacity, polyphenol content, BACE1, and ACE inhibitor activities were very high compared to cooked Koshihikari polished rice.

2. In human tests (15 subjects), BGLs at 90 and 120 min after ingesting cooked HPT KO unpolished rice was significantly lower than those for cooked Koshihikari polished rice $(\mathrm{p}<$ $0.05)$.

3. AUC at $120 \mathrm{~min}$ after eating cooked HPT KO unpolished rice for higher BGL subjects was significantly lower compared to that of cooked Koshihikari polished rice.

4. An increase in the amyloid $\beta 40$ peptide level in the blood at 120 min after the ingestion of cooked HPT KO unpolished rice was slightly lower than that of cooked Koshihikari polished rice.

Therefore, we propose that HPT KO cooked unpolished rice is a promising bio-functional food due to its acceptable physical properties, prevention of an abrupt increase in postprandial BGL, and inhibitory activity against $\mathrm{A} \beta$ production.

Acknowledgments: Part of this research was supported by a Grant in Aid for Scientific Research B (15H02891), C (17K00829), and Strategic Innovation Program (SIP, Cabinet Office, Government of Japan).

Abbreviations: ACE: Angiotensin-Converting Enzyme; ae mutants: Amylose Extender Mutants Of Rice; $A \beta$ : Amyloid $\beta$ Peptide; AUC: Area Under the Curve of the Blood Glucose Response; AD: Alzheimer's Disease; BACE1: $\beta$-secretase; BGL: Blood Glucose Level; CA: Captopril; GABA: Gamma-aminobutyric acid; GI: Glycemic Index; H-ORAC: Hydrophilic-Oxygen Radical Absorbance Capacity; HPT: High-Pressure Treatment; KO: Blend Of Koshihikari and Okunomurasaki Brown Rice; L-ORAC: Lipophilic-Oxygen Radical Absorbance Capacity; PA: Phytic Acid; ROS: Reactive Oxygen Species; RS: Resistant Starch.

\section{References}

1. Ohtsubo, K., Nakamura, S., Maeda, S., et al. Possibility of diabetes prevention by high-amylose rice and super hard rice.(2016) J Diabetes Obes 3(1): 1-7.

Pubmed | Crossref $\mid$ Others

2. Nakamura, S., Satoh, H., Ohtsubo, K. Palatable and bio-functional wheat/rice products developed from pre-germinated brown rice of super-hard cultivar EM10. (2010) Biosci Biotechnol Biochem 74(6): 1164-1172.

Pubmed | Crossref | Others

3. Englyst, H.N., Kingman, S.M., Cummings, J.H. Classification and measurement of nutritionally important starch fractions. (1992) Eur J Clin Nutr 46: S33-S50.

Pubmed | Crossref $\mid$ Others

4. Nakamura, S., Ohtsubo, K. Acceleration of germination of super-hard rice cultivar EM10 by soaking with red onion. (2011) Biosci Biotechnol Biochem 75(3): 572-574.

Pubmed | Crossref | Others

5. Higgins, J.A. Resistant starch: metabolic effects and potential health benefits. (2004) J OAC Int 87(3): 761-768.

Pubmed | Crossref $\mid$ Others

6. Mandal, P.K., Kansara, K., Dabas, A. The GABA-working memory relationship in Alzheimer's disease. (2017) J Alzheimers Dis Rep 1(1): 43-45.

Pubmed | Crossref | Others

7. Kawamura, K., Umemura, T., Hotta., N. Cognitive impairment in diabetic patients: Can diabetic control prevent cognitive decline? (2012) J Diabetes Investig 3(5): 413-423.

Pubmed | Crossref | Others

8. Tokutake, T., Kasuga, K., Yajima, R., et al. Hyperphosphorylation of tau induced by naturally secreted amyloid- $\beta$ at nanomolar concentrations is modulated by insulin-dependent Akt-GSK3 $\beta$ signaling pathway. (2012) J Biol Chem 287(42): 35222-35233.

Pubmed | Crossref | Others

9. Taniguchi, H., Hashimoto, H., Hosoda, A., et al. Functionality of compounds contained in rice bran and their improvement (in Japanese). (2012) Nippon Shokuhin Kagaku Kogaku Kaishi 59(7): 301-318.

Pubmed | Crossref $\mid$ Others

10. Aliev, G., Obrenovich, M.E., Reddy, V.P., et al. Antioxidant therapy in alzheimer's disease: Theory and practice. (2008) Mini Rev Chem 8(13): 1395-1406.

Pubmed | Crossref | Others

11. Sutharut, J., Sudarat, J. Total anthocyanin content and antioxidant activity of germinated colored rice. (2012)Int Food Res J 19(1): 215-221. Pubmed | Crossref $\mid$ Others

12. Nakamura, S., Hara, T., Joh T., et al. Effects of super-hard rice bread blended with black rice bran on amyloid $\beta$ peptide production and abrupt increase in postprandial blood glucose levels in mice. (2017) Biosci Biotechnol Biochem 81(2): 323-334.

Pubmed | Crossref | Others

13. Abe, T.K., Taniguchi, M. Identification of myo-inositol hexakisphosphate (IP6) as a $\beta$-secretase 1(BACE1) inhibitory molecule in rice grain extract and digest. (2014) FEBS Open Bio 4: 162-167.

Pubmed | Crossref | Others 
14. Hayashi, R., Hayashida, A. Increased amylase digestibility of pressure-treated starch. (1989) Agric Biol Chem 53(9): 2543-2544.

Pubmed $\mid$ Crossref $\mid$ Others

15. Hayashi, R. Application of high pressure to food processing and preservation: philosophy and development. (1989) Eng Food 2: 815-826.

Pubmed $\mid$ Crossref $\mid$ Others

16. Kato, T., Katayama, E., Matsubara, S., et al. Release of allergenic proteins from rice grains induced by high hydrostatic pressure. (2000) JAgric Food Chem 48(8): 3124-3129. Pubmed | Crossref | Others

17. Yamakura, M., Haraguchi, K., Okadome, H., et al., Effect of soaking and high-pressure treatment on the qualities of cooked rice. (2005) J Appl Glycosci 52: 85-93.

Pubmed $\mid$ Crossref $\mid$ Others

18. Kinefuchi, M., Sekiya, M., Yamazaki, A., et al. Accumulation of GABA in brown rice by high pressure treatment (in Japanese). (1999) Nippon Shokuhin Kagaku Kogaku Kaishi 46: 323-328.

Pubmed $\mid$ Crossref $\mid$ Others

19. Nakamura, S., Ohtsubo, K. Improvement of palatability and inhibition of abrupt increase in postprandial blood glucose level by the boiled rice after soaking with functional food ingredients.(2015)J Appl Glycosci 62(2): 53-63.

Pubmed | Crossref | Others

20. Folin, O., Denis, W. A colorimetric method for the determination of phenols (and phenol derivatives) in purine. (1915) J Biol Chem 22: 305-308.

Pubmed $\mid$ Crossref $\mid$ Others

21. Prior, R.L., Hoang, H., Gu, L., et al. Assay for hydrophilic and lipophilic antioxidant capacity (oxygen radical absorbance capacity (ORACFL) of plasma and other biological and food samples. (2003) J Agric Food Chem 51(11): 3273-3279.

Pubmed | Crossref | Others

22. Watanabe, J., Oki, T., Takebayashi, J. Improvement of the lipophilic-oxygen radical absorbance capacity (L-ORAC) method and single-laboratory validation. (2013) Biosci Biotechnol Biochem 77(4): 857-859.

Pubmed | Crossref $\mid$ Others

23. Okadome, H., Toyoshima, H., Ohtsubo, K. Muitiple measurements of physical properties of individual cooked rice grains with a single apparatus. (1999) Cereal Chem 76(6): 855-860.

Pubmed $\mid$ Crossref $\mid$ Others

24. Arts, I.C., Hollman, P.C. Polyphenols and disease risk in epidemiologic studies. (2005) Am J Clin Nutr 81 (1 Suppl): 317S-325S.

Pubmed | Crossref | Others

25. Halliwell, B. Antioxidants in human health and disease. (1996) Ann Rev Nutr 16: 33-50.

Pubmed | Crossref | Others
26. Tsuda, T., Horio, F., Uchida, K., et al. Dietary cyaniding 3 - O - beta - D-glucoside - rich purple corn color prevents obesity and ameliorates hyperglycemia in mice. (2003) J Nutr 133 (7): 2125-2130.

Pubmed | Crossref | Others

27. Suzuki, M., Kataoka, T., Ohtsubo, K. Variation in the mineral content of 8 cultivars of pigmented brown rice (in Japanese). (2014) Nippon Shokuhin Kagaku Kogaku Kaishi 61(9): 427-432.

Pubmed | Crossref | Others

28. Qiu, C., Winblad, B., Fratiglioni, L. The age-dependent relation of blood pressure to cognitive function and dementia. (2005) Lancet Neurol 4(8): 487-499.

Pubmed | Crossref | Others

29. Stanton, H.C. Mode of action of gamma amino butyric acid on the cardiovascular system. (1963) Arch Int Pharmacodyn 143: 195-204.

Pubmed | Crossref $\mid$ Others

30. Tsushida, T. Murai, T. Conversion of glutamic acid to $\gamma$-aminobutyric acid in tea leaves under anaerobic conditions. (1987)Agric Biol Chem 51(11): 2865-2871.

Pubmed $\mid$ Crossref $\mid$ Others

31. Hara, Y., Matsuzaki, T., Suzuki, T. Angiotensin I converting enzyme inhibiting activity of tea components (in Japanese). (1987) Nippon Shokuhin Kagakukogaku Kaishi 61(7): 803-808.

Pubmed $\mid$ Crossref $\mid$ Others

32. Panlasigui, L.N., Thompson, L.U. Thompson: Blood glucose lowering effects of brown rice in normal and diabetic subjects. (2006) J Food Sci Nutr 57(3-4): 151-158.

Pubmed | Crossref | Others

33. Jung, E.H., Kim, S.R., Hwang, I.K., et al. Hypoglycemic effects of a phenolic acid fraction of rice bran and ferulic acid in C57BL / KsJ-db / mice. (2007) J Agric Food Chem 55(24): 9800-9804.

Pubmed | Crossref | Others

34. Ishii, Y., Shimizu, F., Ogawa, M., et al. Gender differences in foods uptakes, glycemic index, BMI, and various plasma parameters between young men and women in Japan. (2016) Integr Food Nutr Metab 3: 427-430.

Pubmed | Crossref | Others

Submit your manuscript to Ommega Publishers and we will help you at every step:

- We accept pre-submission inquiries

- Our selector tool helps you to find the most relevant journal

- We provide round the clock customer support

- Convenient online submission

- Thorough peer review

- Inclusion in all major indexing services

- Maximum visibility for your research

Submit your manuscript at OMMEgA Publishers

https://www.ommegaonline.org/submit-manuscript 